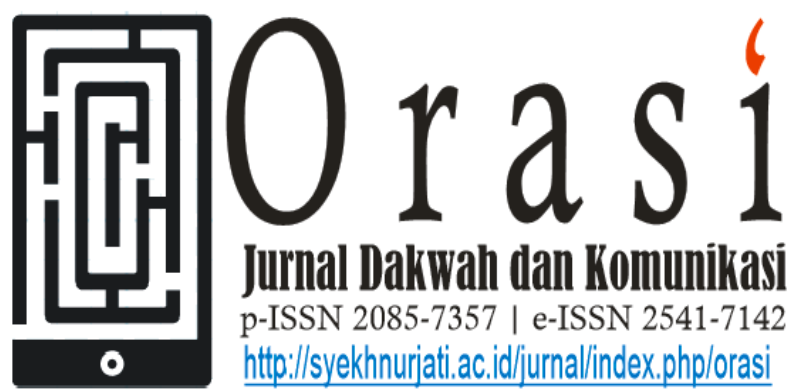

Volume 9 No. 2, PP 43 - 58; November 2018

\title{
DAKWAH QASIDAH MODEREN AL-FALAH MELALUI MUSIK
}

\author{
Asep Kurniawan \\ Dosen IAIN Syekh Nurjati Cirebon \\ asepkurniawan@syekhnurjati.ac.id
}

\begin{abstract}
ABSTRAK
So far da'wah is generally carried out traditionally, i.e. through religious lectures at worship places. This da'wah seems to be focused and preserved. As a result, the target of da'wah does not reach many people especially young people, who need something new and in accordance with their world. For this reason, with the presence of the Modern Qasidah al-Falah gives a new nuance to da'wah, which can be accepted by many young people, because it is presented through musical activities. The purpose of this research is to reveal in depth how far da'wah of Modern Qasidah al-Falah through music. The research approach is qualitative. The instruments of collecting data are indepth observation, in-depth interviews and documentation. The Techniques of analysing data are collecting data, reducting data, displaying data, and conclusing data. The research found that modern qasidah al-Falah music was a combination of elements of modern music while maintaining its Islamic characteristics, those were song lyrics, which were full of invitation to kindness. Da'wah of Modern Qasidah al-Falah through music was carried out in many da'wah areas. The positive impact of this activity was specifically the change in the behavior of its members to good behaviour. Thus, the da'wah of Modern Qasidah al-Falah through music is a new breakthrough for the development of da'wah in order to be accepted by more segmentation of society.
\end{abstract}

Keywords: Da'wah, Music, Modern, Change

\section{PENDAHULUAN}

Nampaknya kesenian Islam di Indonesia mengalami kemacetan yang sudah berjalan sejak lama dalam kehidupan kultur umat Islam. Umat Islam yang sangat berbangga-bangga 
dengan mayoritas jumlah pengikutnya adalah terlalu miskin dalam bidang seni budayanya, suatu ketimpangan dan kepincangan yang sangat serius, karena umat Islam tidak hadir secara kreatif dalam kehidupan kultural masi kini. Jika diteliti secara seksama barangkali umat Islam hanya mempunyai jenisjenis seni budaya, seperti orkes qasidah, orkes gambus, seni rebana, sedikit drama dan beberapa cabang lainnya.

Memang tidak bisa disangkal bahwa secara teologis ajaran-ajaran Islam dengan majunya science dan teknologi justru semakin menyingkap, memperjelas dan mempertegas kebenaran Islam, karena Islam sangat menghargai akal pikiran. Namun begitu, Islam tidak memberikan kedudukan akal setingkat dengan wahyu, yang memberitakan masalahmasalah gaib (supranatural) yang tidak bisa dijangkau dan dipecahkan oleh daya kekuatan akan pikiran manusia. Penetrasi kultur Barat dengan segala jenis dan teknologinya yang mendengunkan slogan "seni untuk seni" telah banyak melanda dan menyusup ke daerah-daerah Islam dan sering begitu saja diterima di kalangan kawula mudanya. Angkatan muda Islam mungkin telah terbina - sadar atau tidak sadar - oleh ekses-ekses seni budaya Barat: mereka sok moderen, ke barat- baratan, sementara mereka begitu antipati dan menjauh seni budayanya sendiri yang bernafaskan Islam. Mereka mungkin lebih terpesona dan menyenangi film-film porno, lagu-lagu erotis, nyanyian dan tarian yang tidak memperlihatkan etika Islam. Sebaliknya mereka kurang menggandrungi kesenian Islam.

Era industrialisasi yang sarat dengan pengaruh globalisasi, antara lain akan menggiring hampir seluruh sisi kehidupan lama ke tata kehidupan baru yang serba menuntut aspek kehidupan berdaya guna untuk kesejahteraan dan kepuasan secara lahiriah. Perubahan ini akan berpengaruh pula terhadap kekayaan seni Islam pada umumnya. Jika tetap statis dan tidak menghiraukan gejala tersebut, tidak tertutup kemungkinan seni tradisi akan tergilas dan mungkin juga masuk tong sampah.

Sebagaimana layaknya bangsa yang sedang mengalami proses industrialisasi, masyarakat Indonesia akan terus berkembang dan bergeser dari strukturnya yang tradisional menuju struktur moderen. Perubuhan struktur masyarakat tersebut sangat kompleks dan berdimensi banyak (multi dimensi) sehingga menimbulkan berbagai perubahan mendasar dalam berbagai bidang kehidupan masyarakat. Transformasi tersebut berlangsung 
sebagai bagian dari berkembangnya sektor-sektor fungsional yang ditandai dengan munculnya jenis-jenis jabatan baru yang semakin aneka ragam yang mengakibatkan timbulnya berbagai bentuk perubahan fisik pranata sosial dan pergeseran nilai.

Peralihan ini sudah menampakkan pada adanya benturan-benturan nilai, kesenjangan-kesenjangan di antara nilai-nilai juga kesalahfahaman, kesimpangansiuran serta konflikkonflik internal dalam tata kehidupan termasuk dalam berkesenian. Hal ini nampak dari masih banyaknya di berbagai kalangan masyarakat seni yang ragu, bingun, kehilangan pegangan dan juga yang keliru menafsirkan cara menghidupkan dan mendayagunakan seninya sebagai produk industri budaya. Apalagi dengan semakin transparan dan membanjirnya produk-produk baru lewat panggungpanggung hiburan dan lewat tayangan televisi, baik produk budaya asing maupun produk dalam negeri yang tidak bermantra lagi pada budaya negerinya sendiri. Arus globalisasi ini betul-betul memberikan dampak yang semakin mencemaskan dan tentu akan berpengaruh terhadap sikap berkeseniannya.

Fenomena yang nampak di era globalisasi ini dapat dilihat dari sebagian angkatan muda Islam yang telah 'menyeberang' ke kebudayaan Barat tanpa awas ekses-ekses negatif yang akan menimpanya. Ekses-ekses negatif ini tidak dapat dipungkiri setidaknya dibuktikan oleh sejumlah penelitian tentang kesenian, seperti penelitian Rukmana (2015) menemukan fakta bahwa musik DJ berpengaruh pada perilaku pengunjung Liquid Café Semarang berupa perilaku seks bebas, perilaku konsumtif, perilaku minumminuman keras, perilaku malas, dan terhadap penampilan pengunjung Liquid Café Semarang, yaitu penampilan yang senantiasa ingin terlihat casual.

Ini semua bukan sepenuhnya kesalahan mereka. Oleh karena itu keadaan ini perlu didiagnosis, baru dilakukan terapi terhadap gejala tersebut. Pada hemat saya, diagnosis terhadap gejala tersebut ada dua kemungkinan. Pertama, kesenian umat Islam berjalan dan hidup secara tradisional, itu-itu juga, mandeg sehingga kurang menarik minat dan selera di kalangan angkatan muda. Kedua, seni budaya Islam kurang kreatif inovatif dan variatif, ketinggalan dalam bobot dan kualitas. Dua kemungkinan itulah yang menjadi penyebab utama mengapa sebagian generasi muda Islam lebih menyenangi 
kebudayaan Barat dan kurang menyenangkan seni budaya Islam.

Kecemasan-kecemasan yang menimpa masyarakat penggiat seni Islam, harus segera di atasi sebab akan berakibat fatal jika dibiarkan berlarutlarut. Ahli terapi kognitif IVY. Maris Blackburn dan Kate M. Davidson mengemukakan bahwa kecemasankecemasan berawal dari gangguan pikiran, kemudian simtom-simtom psikologi dalam pikirannya menimbulkan kekhawatiran, sukar berkonsentrasi, pikiran kosong, membesar-besarkan ancaman, memandang diri sangat sensitif dan merasa tidak berdaya serta menghindari situasi ketergantungan tinggi dan ingin melarikan diri. Karena itu, tidak mengherankan jika terjadi kemandegan aktivitas berkesenian dan kekayaan seni Islam bisa menjadi punah atau mungkin juga salah arah dalam aktivitas menghidupkan dan mendayagunakan seni Islam itu sendiri.

Maka sebagai terapi terhadap gejala ini sudah waktunya bagi umat Islam - terutama para seniman dan budayawannya - menciptakan kreasi, inovasi dan pengayaan baru di bidang seni budaya Islam moderen yang memenuhi standar kualitas estetika. Jika ini dapat dilakukan, maka terciptalah gairah dan etos kerja yang besar, yang dapat mendorong kesenian dan kebudayaan Islam berkembang maju, baik dalam kualitas maupun kuantitas. Dengan demikian, kesenian dan kebudayaan Islam akan mendapat posisi penting dan terhormat dalam kancah kehidupan seni budaya lainnya. Untuk itu, tidak ada jeleknya bagi seniman dan budayawan Islam mempelajari improvisasi-improvisasi dan tehnik penggarapan seni budaya luar dengan maksud mengambil inspirasi dan manfaat dan hal-hal yang positif bagi pengembangan seni budaya Islam. Tentu saja, dengan sendirinya, nilainilai yang tidak sesuai dengan semangat dan wawasan Islam hendaknya ditinggalkan. Mempelajari dan mengambil manfaat dari hal-hal baik adalah sangat perlu, bahkan seharusnya dikerjakan bagi pengembangan kreativitas seni budaya Islam khususnya demi kepentingan dalam menyebarluaskan ajaran Islam (dakwah). Kepentingan ini membutuhkan adanya sentuhan kreativitas seni untuk dapat diterima oleh sasaran dakwah.

Kita memahami bahwa agama Islam ialah agama dakwah, sebab ia diperkenalkan dan disebarluaskan kepada umat manusia melalui kegiatan dakwah, tanpa melalui kekuatan senjata, pemaksaan, atau kekerasan. 
Oleh karena itu dakwah adalah aktivitas wajib bagi setiap muslim. Kewajiban ini dilakukan dengan cara mengajak umat manusia kepada kebaikan dan mencegahnya dari kemungkaran (menegakkan amar ma'ruf nahi munkar). Dakwah adalah perwujudan dari keislaman seseorang, hal ini bisa disosialisasikan melalui banyak macam bentuk atau media, dengan tidak mengurangi arti dan tujuan dari dakwah itu sendiri. Sebab dakwah memiliki berbagai macam bentuk atau media. Contoh seorang berdakwah dengan ceramahnya, penyair dengan syairsyairnya, seniman dengan karya seninya, dan seorang musisi mengekspresikan imajinasi suara melalui musik.

Musik adalah diantara media dakwah yang memiliki peran besar dalam menyampaikan pesan dakwah kepada umat manusia. Sebab hampir setiap sasaran dakwah atau masyarakat lazimnya menyenangi musik. Al-Farabi seorang komposer musik yang terkenal pada masanya, dapat mengkomposisi banyak jenis musik dalam sejumlah cara. Cara yang dipakai berbeda-beda menselaraskan dengan jenis situasi kejiwaan manusia, sehingga ia mudah dan cepat menerima pesan yang disampaikan melalui lagu yang dinyanyikan (Rahmayanti, 2016: iv).
Dewasa ini musik-musik bertema keagamaan tidak hanya pada aliranaliran tertentu saja, semisal qasidah tradisional dengan rebana sebagai ciri khasnya. Sejalan dengan perkembangan dari waktu ke waktu, bermunculan lagu-lagu religi dengan genre musik moderen, baik pop, rock, gamelan, ataupun qasidah yang sudah mendapatkankan sentuhan moderen.

Kehadiran qasidah moderen di ranah musik religi menunjukkan bahwa tidak mesti menjadi seorang ustadz, muballig ataupun kyai untuk dapat berdakwah. Terlepas dari profesi apa yang seseorang miliki, di manapun dan kapanpun seseorang berada, dalam masyarakat apapun seseorang hidup, ia tetap harus berdakwah selaras dengan kemampuan dan kapasitas masingmasing. Kehadiran qasidah moderen dalam belantika musik di tengah masyarakat juga bisa menambah pengetahuan dan wawasan kita tentang sangat beragamnya media dakwah.

Lahirnya grup Qasidah Modern al-Falah misalnya, selain muncul sebagai eksperimen dan sarana dakwah islamiyah, agaknya merupakan usaha untuk mendobrak dan memecahkan ketidakpuasan terhadap gaya keseniaan Islam tradisional yang mapan, tanpa menghilangkan nilai-nilai Islamnya. Qasidah moderen cukup banyak diuji, 
karena di dalam pengembangan demikian masih saja ada yang kurang. Kekurangan itu, barangkali yang menyebabkan timbulnya sikap pro dan kontra. Sikap pro dan kontra dalam suatu masalah adalah suatu hal yang wajar. Namun betapa pun, Qasidah Modern al-Falah merupakan sebuah contoh kecil. Sebagai langkah baru dalam perjalanan kehidupan seni budaya Islam di Indonesia, qasidah moderen pada umumnya dan Qasidah Moderen al-Falah pada khususnya menyiratkan dan menyuguhkan sesuatu yang baru paling tidak baru bagi penggemarnya. Grup Bimbo yang menyanyikan lagu-lagu religi dan Taufiq Ismail dengan puisi-puisi yang sarat dengan nilai-nilai Islam, pada waktunya merupakan 'kreasi baru' yang menyegarkan spiritualitas dalam kehidupan dan pertumbuhan seni budaya Islam. Begitu pula, Gamelan Kiai Kanjeng hasil kreasi dan inovasi Emha Ainun Nadjib misalnya adalah satu improvisasi lain yang bisa dijadikan semacam 'laboratorium' dan 'cermin' terbaik bagi kita, bahwa pengembangan dan penyegaran dalam bidang seni budaya Islam merupakan suatu kebutuhan mendesak di tengah mewabahnya musik-musik dekaden atau yang merusak moral dan budaya bangsa.
Kendatipun demikian munculnya Qasidah Moderen al-Falah tidak hanya sebatas inovasi di bidang seni budaya Islam semata, namun lebih jauh telah berakibat pada perubahan perilaku masyarakat. Seni telah dimanfaatkan secara efektif untuk tujuan dakwah Islamiyah dan sebagai wadah berkumpul dalam pengintegrasian masyarakat. Oleh karena itu hal ini sangat menarik penulis untuk mengangkat lebih jauh dalam suatu kajian penelitian.

\section{METODE PENELITIAN}

Metode penelitian yang dipergunakan dalam penelitian ini adalah penelitian kualitatif deskriptif naturalistik. Dalam pengumpulan data dilakukan dengan cara observasi mendalam, wawancara mendalam, dan studi dokumentasi. Seluruh data yang terkumpul kemudia dianalisis dengan dibantu studi pustaka untuk mendukung dan melengkapi data-data yang telah terkumpul. Observasi pendahuluan dimulai pada 27 Mei 2017 sekaligus wawancara dengan para personil dan pimpinan Qasidah Modern al-Falah sampai tanggal 6 Juni 2017. Penelitian kemudian dilanjutkan secara intensif sampai penyusunan laporan penelitian September 2018. Data yang diperoleh kemudian disusun dalam bentuk 
deskripsi dan dianalisis melalui studi pustaka untuk lebih memperkuat pandangan dan interpretasi penulis terhadap obyek yang diteliti.

\section{EKSISTENSI QASIDAH AL-} FALAH

Qasidah Moderen al-Falah merupakan organisasi kesenian yang terdaftar di Kementerian Pendidikan dan Kebudayaan Kabupaten Kuningan dengan Nomor Akta Pendirian 220/102.16/KPTS/J/1996 dengan tanggal pengesahan 14 Mei 1996. Berdasarkan akta pendidirian tersebut menunjukkan bahwa Qasidah Moderen al-Falah merupakan perkumpulan atau organisasi resmi.

Qasidah Moderen al-Falah pada mulanya masih bersifat tradisional. Personilnya terdiri dari depalan orang, yang terdiri dari satu orang berperan sebagai vokalis inti dan yang lainnya sebagai pemain musik pengiring dengan alat musik rebana. Berdirinya kelompok musik ini muncul berawal dari penyelenggaraan festival qasidah tradisional tingkat kewadanan Cilimus pada tanggal 7 Agustus 1995 oleh muslimat NU. Tujuan dari festival ini adalah untuk melestarikan budaya Islam tradisional dan menyalurkan bakat seni di kalangan generasi muda. Di antara pesertanya adalah guru-guru Taman
Pendidikan al-Qur'an Ade Irma Suryani Nasution Cilimus yang diketuai oleh Eli Halimah. Di luar dugaan grup qasidah ini menjadi juara umum I.

Dari festival tersebut, orkes tradisional ini mulai dikenal masyarakat. Undangan demi undangan pentas terus mengalir. Undangan itu ditujukan untuk mengisi acara hiburan dalam kegiatan-kegiatan yang bernuansa keagamaan, seperti acaraacara keagamaan di masjid dan mushalla, lomba kebersihan desa, peresmian Ikatan Persatuan Haji Indonesia (IPHI) cabang Cilimus, dan lain-lain.

Latihan rutin dilakukan pada setiap malam minggu selama tiga jam di rumah Eli Halimah. Tujuan dari latihan ini adalah untuk lebih memperkaya wawasan dan kemampuan seni qasidah tradisional. Koleksikoleksi lagu semakin lama semakin bertambah. Ketika menguasai kurang lebih empat puluh lagu frekwensi latihan dikurangi menjadi dua minggu satu kali.

Eli Halimah dan suaminya, yaitu Asep Saefullah menangkap gejala kecenderungan minat masyarakat terutama kawula mudanya kepada musik qasidah tradisional sangat kecil. Mereka lebih tertarik kepada musikmusik pop, rock, dangdut dan 
khususnya musik-musik yang datangnya dari Barat. Disamping itu adanya gejala negatif di kalangan anak muda sebagai akibat dari pengangguran dan tidak tersalurkannya bakat seni mereka. Dari sini muncul gagasan untuk mendirikan orkes qasidah moderen.

Disebut moderen, karena ia adalah modifikasi dari musik dangdut melalui perubahan harmonisasi musik dan syair-syair yang diarahkan kepada karakter yang bericirikan Islam. Alat musik rebana sebagai unsur utama musik pengiring qasidah yang orisinil sudah diganti fungsinya oleh gendang. Perpaduan alat-alat musik yang satu dengan yang lain yang nota bene musik moderen, seperti organ string, organ rhythm, gitar bass, gitar melodi, dan biola. Alat-alat tersebut mampu berjalan kompak dan serasi membentuk suatu harmonisasi musik qasidah moderen yang enak didengar.

Eksistensi qasidah moderen mendapat dukungan dari Dadang seorang direktur PT Rama Putra Jakarta dan adik kandung Asep - dengan pemberian dana yang cukup besar untuk pembelian alat-alat musiknya. Tercatat biaya awal yang telah dikeluarkan untuk alat ini, yaitu Rp. 24.845.000 di tahun 1996. Organisasi kesenian ini resmi didirikan pada tanggal 14 Mei
1996 dengan nama Qasidah Moderen al-Falah. Kantor dan tempat latihan di rumah Eli Halimah dan Asep Saefullah, mereka berdua sekaligus sebagai pimpinan. Anggota-anggotanya direkrut dari masyarakat sekitar yang mempunyai potensi di bidang seni. Di samping sebagai media dakwah, penyalur hobby di bidang seni musik. Qasidah Moderen al-Falah juga bergerak di bidang bisnis sebagai penyelenggara jasa entertainment. Jadwal latihan meneruskan apa yang telah dilakukan sewaktu masih menjadi qasidah tradisional, yaitu satu kali dalam satu minggu setiap sabtu malam.

Di dalam memasarkan dan mempromosikan bisnis ini dilakukan beberapa upaya, seperti menyebarkan kartu nama, pemberitahuan melalui relasi, teman-teman, dan lain-lain. Pementasan-pementasan dengan harga sewa yang relatif murah. Melalui upaya ini dapat membuahkan hasil dengan datangnya permintaan pentas pada acara hajatan pernikahan di Ciloklok Cilimus, kemudian permintaan itu semakin lama semakin banyak, terhitung selama tahun pertama berdirinya Qasidah Moderen al-Falah sudah tidak terhitung pementasan di berbagai tempat di Kabupaten Kuningan, Cirebon, Majalengka, bahkan ke tempat yang lebih jauh 
seperti Brebes, Tanggerang, Jakarta, Kebumen, dan lain-lain. Selain itu pendapatan organisasi kesenian ini selain dari pementasan adalah penyewaan alat-alat musik sebagai atau keseluruhan. Namun terakhir ketika penulis menyelesaikan penelitian ini alat-alay musik tersebut sudah dijual. Walaupun demikian Qasidah tetap eksis dengan menyewa alat dari grup yang lain. Alasannya adalah biaya pemeliharaan yang sangat besar.

Anggota Qasidah Moderen alFalah berjumlah total dua puluh orang. Anggota sejumlah itu diperlukan dalam pementasan. Namun dalam kondisi latihan rutin hanya melibatkan sekitar lima belas orang saja. Hal ini disebabkan pada kegiatan latihan tidak diperlukan asisten teknisi dan seorang MC.

Seluruh anggota direkrut dari masyarakat desa setempat dengan melihat dari sisi keahlian mereka di bidang seni musik dan olah vokal, misalnya dari kampung Cinangka, Padahayu, Ciloklok. Kedekatan domisili ini berakibat pada hubungan yang akrab baik antara anggota dengan anggota maupun antara anggota dengan pimpinan. Bahkan ada beberapa anggota yang masih memiliki hubungan kerabat dengan anggota yang lain. Sebagian dari mereka sudah menikah dan sebagian yang lainnya masih berstatus lajang. Latar belakang pendidikan umunya lulusan SLTA dan selebihnya lulusan perguruan tinggi. Namun ijazah yang mereka sandang tidak mereka pergunakan untuk mencari pekerjaan yang sesuai dengan disiplin ilmunya. Mereka lebih tertarik untuk menjadi pedagang, pengojek dan lainlain. Sebagian yang lainnya masih menganggur.

Berdasarkan hasil wawancara penulis dengan beberapa personil, jasa entertainment ini tidak diandalkan sebagai penghasilan pokok bagi mereka atau dengan perkataan lain keuntungan dari usaha ini hanya cukup dijadikan sebagai usaha sambilan dan tambahan penghasilan rutin sehari-hari, walaupun di pihak lain bagi mereka yang masih menganggur menganggapnya sebagai pekerjaan yang diandalkan. Hal in disebabkan pementasan dan penyewaan alat-alat tidak muncul rutin dan stabil dalam tenggang waktu yang relatif dekat. Kadangkala dalam satu bulan tidak ada pementasan dan penyewaan alat sekalipun, namun kadangkala pula dalam satu bulan berikutnya terjadi pementasan dan penyewaan alat satu sampai 3 kali. Di samping itu untuk tiap personilnya mendapat penghasilan untuk setiap satu kali pentas bekisar antara Rp. 150.000 sampai 200.000 . 
Jumlah itu relatif kecil untuk memenuhi kebutuhan hidup mereka sehari-hari.

Beberapa anggota memiliki keanggotaan rangkap. Mereka selain tergabung dengan Qasidah Moderen alFalah juga menjadi personil kelompok musik yang lain. Namun mereka lebih mengutamakan kegiatan di Qasidah Moderen al-Falah, jika terjadi bentrokan jadwal kegiatan antara keduanya.

Pada mulanya mereka masih awam terhadap penguasaan musik qasidah moderen. Namun berbekal semangat dan usaha keras melalui latihan-latihan rutin setiap minggunya, kemampuan penguasaan jenis musik ini sediki demi sedikit dapat mereka kuasai. Apalagi musik qasidah moderen tidak banyak memerlukan improvisasi seni dan kemampuan dasar musik yang tinggi.

\section{Dakwah Qasidah al-Falah melalui} Musik

Dalam setiap kali latihan qasidah, sering sekali dibuka dengan pengarahan dan wejangan dari Asep Saefullah selaku pimpinan Qasidah Moderen alFalah. Dalam kesempatan yang lain ceramah keagamaan di sela-sela latihan disampaikan oleh dewan pembina yaitu Hamdani, dan tokoh-tokoh ulama Desa Cilimus. Nilai-nilai ketakwaan dan keimanan sangat ditekankan di sini. Mereka senantiasa mengingatkan agar para anggota selaku pembawa dakwah Islam melalui musik dapat menjaga nama baik dan memberi contoh teladan kepada masyarakat.

Pengarahan ini tidak hanya berkaitan dengan musik qasidah, tetapi juga nasehat keagamaan untuk meningkatkan kualitas amal ibadah, keimanan dan ketaqwaan semua anggoata terhadap Tuhan. Belum lagi lagu-lagu qasidah yang dinyanyikan sarat dengan pesan-pesan dakwah. Sebut saja lagu Bismillah, yang ketika peneliti amati dalam latihan mereka, sarat dengan pesan untuk senantiasa mengawali semua kegiatan dengan bismillah, berdoa dan bertawakkal. Bisa kita lihat lirik lagu yang dimaksud: 
Bismillah tawakkalna billah, Bismillah tawashalna billah, $2 \mathrm{x}$ Bismillah tawakkaltu 'alallah.

Bismillah, Bismillah, Bismillah,

Bismillah, Bismillah,

Bismillah tawakkalna billah, Bismillah tawashalna billah,

Bismillah tawakkaltu 'alallah.........

Bismillah, Bismillah, Bismillah,

Bismillah, Bismillah,

Reff

Bismillah ya rahmanu ya rahim

Bismillah ya allah ya karim

Bismillah ya rahmanu ya rahim

Bismillah ya allah ya karim

Bismillah ya dzal jalali wal ikrom.

Bismillah, Bismillah, Bismillah

Bismillah, Bismillah

Bismillah tawakkalna billah, Bismillah tawashalna billah, $2 \mathrm{x}$

Bismillah tawakkaltu 'alallah.........

Bismillah, Bismillah, Bismillah,

Bismillah, Bismillah,

Reff

Bismillah ya tawafhtu 'alaina

Bismillah ya Allah irhamna

Bismillah ya tawafhtu 'alaina

Bismillah ya Allah irhamna

Bismillah ya jathuna wal iqdhom

Bismillah, Bismillah, Bismillah

Bismillah, Bismillah

Bismillah tawakkalna billah, Bismillah tawashalna billah, 2x

Bismillah tawakkaltu 'alallah.

Bismillah, Bismillah, Bismillah,

Bismillah, Bismillah,

Demikian pula dengan lagu-lagu qasidah yang lain, seperti ya Rabbi Barik, yang mengandung makna untuk meminta keberkahan hidup dari Sang Pencipta, Marhaban yang bermakna ucapan selamat datang sebagai kecintaan dan sholawat kepada Rasulullah saw, Nabi Muhammad Mataharinya Dunia yang memiliki lirik puitis yang sarat dengan pesan dakwah, yaitu rasa bahagia dan syukur atas anugerah Nabi Muhammad sebagai matahari dunia yang bersinar abadi sepanjang zaman, rahmat seluruh alam dan ajakan untuk bershalawat kepadanya. Selain lagu-lagu tersebut, tentu masih banyak lagi lagu qasidah yang lain dan penuh dengan muatan dakwah.

Muatan dakwah yang lain disampaikan oleh Asep Saefullah adalah dakwah mengenai kreatifitas dalam berseni. Walaupun Qasidah Moderen al-Falah menyanyikan lagulagu religi yang pernah dan diciptakan oleh grup qasidah yang lain, tetapi Asep mengarahkan kepada anggotanya untuk melakukan improvisasi terhadap lagu tersebut. Itu dilakukan dalam latihan yang senantiasa direkam kemudian setelah itu rekaman diperdengarkan kembali dan dibandingkan dengan lagu aslinya, selanjutnya diimprovisasi.

Improvisasi ini dilakukan dengan pengubahan aransemen oleh Asep lalu dimusyawarahkan dengan para anggota dan terus disempurnakan dalam setiap latihannya. Disamping itu lagu-lagu yang dinyanyikan telah disesuaikan dengan karakter vokal dari masingmasing penyanyi sehingga enak untuk didengar. Tujuan dari itu semua adalah agar pesan dakwah yang disampaikan dalam lagu-lagu qasidah moderen dapat diterima di berbagai kalangan yang tidak hanya para orang tua tetapi anakanak muda melalui konsep musik moderen.

Tidak dapat dipungkiri dengan semakin deras dan bermunculan jenis aliran musik moderen telah mampu 
menarik dan menggeser minat masyarakat dari tradisi. Pada sisi inilah Qasidah Moderen al-Falah mampu menawarkan sesuatu yang lain yang sesuai dengan kecenderungan masyarakat itu tanpa meninggalkan nilai-nilai agama dan norma-norma budaya masyarakat. Oleh karena itu, tidak terlihat dalam setiap kali penampilan grup musik ini baik dalam latihan maupun dalam pementasan adanya gerakan-gerakan erotis. Pakaian yang mereka kenakan pun harus syar'i. Artinya tidak hanya segi keindahan dan keserasian yang ditampilkan, tetapi lebih dari itu kepentingan untuk menutup aurat.

Keberadaan Qasidah Moderen alFalah dapat diterima oleh masyarakat sekitar. Penerimaan ini terlihat dari cukup antusiasnya mereka setiap kali latihan dilaksanakan yang umumnya anak-anak muda. Mereka memperhatikannya dan menikmati jalannya latihan melalui pintu dan jendela yang sengaja dibiarkan terbuka. Sesekali Asep dan Eli menemui mereka, mengajak berbincang-bindang dan mempersilahkan untuk masuk, akan tetapi mereka menolaknya. Upaya itu dilakukan untuk mendekatkan diri dengan masyarakat.

Secara lebih dalam konteks Desa Cilimus. Keberadaan Qasidah Moderen
al-Falah diterima dengan baik, sebab seluruh penduduk Desa adalah beragama Islam. Mereka menyenangi warna musik yang religius, sehingga dapat melekat di hati. Lebih dari itu, dukungan dari para alim ulama terhadapnya, seperti penempatan salah seorang ulama sebagai dewan penasehat, mampu memperkuat eksistensi Qasidah Moderen al-Falah di tengah-tengah misi dakwah ke masyarakat.

Penulis melihat dakwah melalui seni ini adalah suatu terobosan di tengah pakem dakwah yang selama ini lebih banyak dilakukan melalui ceramah-ceramah keagamaan di masjid, majlis taklim atau mushalla-mushalla. Lebih jauh terlihat internalisasi pesan agama dibungkus dalam suasana yang tidak membosankan. Karena memang secara bukti ilmiahpun musik dapat menciptakan suasana ceria dan bahkan dapat mengurangi kelelahan (Prawidhana dan Prabowo, 2015: 9). Para pemain dan masyarakat cukup senang menikmatinya dan cukup dapat mengobati kehausan relung rohani. Fenomena ini diyakini dapat ikut meredam agresifitas yang sering lekat pada jiwa usia muda. Hal ini sebagaimana dibuktikan dalam penelitian Aprini dan Prasetya (2018) terapi musik klasik efektif guna 
menurunkan resiko perilaku kekerasaan pada pasien skizofrenia dengan perilaku kekerasan. Pasien yang mengalami perilaku kekerasan bisa mengontrol gejala dan tanda dengan terapi musik klasik supaya tidak sampai terjadi gangguan pada kejiwaan.

Bukan sesuatu yang melanggar norma, menurut penulis, di sela-sela latihan, para pemain Qasidah Moderen al-Falah memainkan genre lagu yang lain semisal dangdut sehingga suasana tidak membosankan. Mereka dan masyarakat yang menyaksikan bergoyang mengikuti irama lagu. Canda tawa menghiasi suasana, sehingga menjadi semarak dan penuh keakraban.

Melalui kreativitas bermusik, para anggota Qasidah Moderen al-Falah yang sebagian besar anak-anak muda tersalurkan hobi dan bakatnya. Disamping itu mereka senantiasa mendapatkan internalisasi nilai dari pesan-pesan pimpinan qasidah sebagai tokoh yang cukup disegani, dan juga internalisasi melalui pesan-pesan dakwah dalam lirik lagu qasidah yang mereka nyanyikan. Sebenarnya dari sejumlah kru personil Qasidah al-Falah ada diantaranya yang memiliki kebiasaan buruk seperti mabukmabukkan, dan tidak melaksanakan shalat sebagaimana mestinya, atau mereka sering menomor sekiankan ibadah penting ini. Namun karena mereka berkumpul dalam komunitas religi, mau tidak mau mereka mendapatkan pengaruh baik untuk merubah kebiasaan buruknya. Mereka jadi malu manakala sudah masuk waktu shalat, namun mereka tidak segera mendirikan shalat, karena temantemannya di dalam grup sudah menunaikan shalat berjamaah, dan mereka pun malu serta terhadap ketokohan Eli Halimah atau Asep Saefullah selaku pimpinan kelompok. Terlebih tindakan amoral yang lain, yaitu mabuk-mabukkan, mereka berupaya mengurangi dan menghilangkannya seiring nasehat yang sering disampaikan pimpinan Qasidah Moderen al-Falah ini. Rasa sungkan mereka rasakan sebab atribut atau nama kelompok musik yang berafiliasi kepada keagamaan. Menurut pengakuan beberapa anggota bahwa perilaku buruk mabuk-mabukan ini disebabkan pengaruh lingkungan sebelumnya ketika ia masih bergabung dengan grup musik dangdut dan lingkungan dimana ia tinggal.

Untuk itu nasehat Asep Saefullah dilakukan secara pribadi terhadap beberapa oknum yang melakukan perbuatan tercela. Contohnya, penulis mendapati fakta ada seorang anggota dengan inisial L dilaporkan oleh teman- 
teman sesama anggota Qasidah Moderen al-Falah bahwa mereka mendapatinya di suatu malam bermabuk-mabukan. Maka pada saat yang tepat orang yang bersangkutan diajak berdialog secara empat mata. Asep menasehatinya untuk tidak melakukan perbuatan itu kembali. Disamping itu upaya untuk saling mengingatkan dilakukan pula oleh sesama anggota Qasidah Moderen alFalah.

Adanya pengaruh positif melalui aktivitas Qasidah Moderen al-Falah adalah terisinya waktu luang khususnya para anggota qasidah kepada hal-halnya yang bersifat positif, yaitu pengembangan bakat dan minat. Pengisian kekosongan waktu ini semakin meminimalisir kesempatan mereka untuk berbuat di luar syariah Islam. Fenomena ini setidaknya dapat penulis tangkap dari semakin sedikitnya waktu bagi mereka untuk nongkrongnongkrong di pinggir jalan yang tidak jarang terjadi gesekan dengan kelompok kawula muda yang lain.

Dakwah melalui musik bisa diterima sebab hal ini masuk ke dalam relung-relung ekspresi keindahan berseni yang merupakan sifat fitrah manusia. Dakwah melalui musik, sama halnya juga terapi kesehatan jiwa melalui musik bermanfaat guna gejala psikosis. Sebagaimana sudah dibuktikan dalam penelitian Michael J. Silverman (2003: 27-40) melalui riset kuantitatifnya bahwa musik telah terbukti sangat efektif dalam menekan dan melawan gejala-gejala psikosis $(\mathrm{d}=$ $+0,71)$. Musik yang dimaksud adalah seluruh jenis musik, live atau bukan live. Penelitian ini juga sekaligus membantah bahwa musik yang baik untuk pengobatan adalah musik klasik.

Sejumlah penelitian yang lain membuktikan bahwa musik dalam menciptakan mood dalam bekerja. Sehingga diyakini dakwah melalui seni khususnya qasidah dapat lebih mudah diterima karena bisa membangkitkan mood dalam beraktivitas sekaligus menerima internalisasi nilai-nilai. Penelitian yang dimaksud diantaranya penelitian Ayça Berfu Ünal dan Linda Steg Kai Epstude. Mereka menemukan fakta bahwa mendengarkan musik meningkatkan upaya mental saat mengemudikan kendaraan yang selanjutnya dapat meningkatkan peforma mengemudi.

Para anggota Qasidah Moderen al-Falah dapat menumpahkan perasaannya lewat irama lagu dan ritme musik yang indah. Mereka pun dapat memberikan komentar berupa pujian atau sebaliknya berupa kritikan yang dibungkus canda tawa terhadap 
permainan para anggota sebagai refleksi apresiasi mereka terhadap seni. Hal ini dapat berasal dari para anggota sendiri ataupun dari masyarakat sekitar yang menyaksikan mereka berlatih. Oleh karena itu, tidak berlebihan kiranya jika dikatakan bahwa musik adalah bahasa emosi dengan ungkapan "music has been called the language of the emotions (Patel. 2003: 674). Musik juga adalah salah satu kebutuhan hidup yang harus dipenuhi oleh manusia adalah kebutuhan terhadap estetika atau kesenian yang terintegrasi ke dalam berbagai kebutuhan hidup lainnya (Kodiran, 1998).

Internalisasi nilai tidak saja berlangsung ketika Qasidah Moderen al-Falah berlatih rutin tetapi juga dalam acara-acara pementasan di berbagai daerah. Bisanya kehadiran Qasidah Moderen al-Falah ini sebagai penambah, pelengkap, atau penyemarak di acara-acara keagamaan seperti tablig akbar, pertemuan organisasi keagamaan, dan lain-lain. Sehingga kegiatan dakwah ini semakin menjadi lebih berwarna dan mengurangi suasana yang monoton. Disamping itu, mereka juga mengisi kegiatan di acara non keagamaan seperti acara pernikahan, dan lain-lain.

Contoh, pementasan Qasidah Moderen al-Falah merupakan gabungan dengan acara tabligh. Biasanya ditempatkan di akhri acara setelah ceramah dari seorang mubalig. Semacam kegiatan nada dan dakwah. Dengan demikian, para penontong tidak terdorong untjk bersikap agresif dan anarkis. Berbeda kondisinya jika dilihat pada pementasan jenis musik yang lain, seperti dangdut atau rock yang sering menimbulkan keributan dan kebringasan.

\section{PENUTUP}

Qasidah Moderen al-Falah eksis dalam kegiatan kesenian religi dan dakwah yang dapat diterima masyarakat. Kreatifitas kesenian yang grup ini tawarkan memberikan warna dakwah melalui musik yang cukup selaras dengan kecenderungan masyarakat. Mereka mendambakan sesuatu yang "baru" guna mendobrak kebosanan dan ketidakpuasan terhadap pakem dakwah yang itu-itu saja, yaitu tradisional dan statis. Gaya moderen yang mereka usung untuk kepentingan dakwah, dengan inovasi dan improvisasi musik-musik moderen tanpa menghilangkan nilai-nilai keislaman dan memenuhi standar kualitas estetika.

Melalui aktivitas berkesenian, Qasidah Moderen al-Falah berupaya memberikan internalisasi nilai-nilai religi dari pesan-pesan rilik lagu yang 
dinyanyikan kepada masyarakat.

Disamping itu grup ini berupaya menciptakan interaksi dakwah secara internal terhadap anggota-anggotanya untuk senantiasa menjadi figur-figur yang melaksanakan ajaran Islam.

\section{DAFTAR PUSTAKA}

Kodiran. 1998. Kesenian dan Perubahan Masyarakat. Simposium Internasional Ilmu-ilmu Humaniora $\mathrm{V}$, pada tanggal $8-9$ Desember 1998 yang diselenggarakan oleh Fakultas Sastra, Universitas Gajah Mada. Tidak diterbitkan.

Patel, Aniruddh D. 2003. "Language, Music, Syntax and the Brain", dalam Nature Neuroscience. Volume 6, Issue 7, Nature publishing group 674

Prawidhana, Witha Anjar dan Sumbodo Prabowo. 2015. "Pengaruh Musik terhadap Kelelahan Kerja," Prikodimensia, Vol. 14, 2, 2015. Semarang: Fakultas Psikologi Universitas Katolik Soegijapranata Semarang. 9-17.
Rahmayanti, Siti Rahayu. 2016. Pengaruh Musik terhadap Kejiwaan Manusia menurut al-Farabi: Studi Kasus Musik Gambus el Syamwel Cilandak Jakarta Selatan. Jakarta: Jurusan Aqidah dan Filsafat Islam, Fakultas Ushuluddin, Universitas Islam Negeri Syarif Hidayatullah Jakarta

Rukmana, Febri Indra. 2015. Pengaruh Musik DJ terhadap Persepsi, Perilaku, dan Penampilan para Pengunjung di Liquid Café Semarang. Skripsi. Semarang: Jurusan Pendidikan Seni Drama, Tari, dan Musik, Fakultas Bahasa dan Seni, Universitas Negeri Semarang.

Silverman, Michael J. MM, MT-BC. 2003. "The Influence of Music on the Symptoms of Psychosis: A MetaAnalysis," dalam Journal of Music Therapy, Volume 40, Issue 1, 1 March 2003, 27-40.

Ünal, Ayça Berfu dan Linda Steg Kai Epstude. 2012. "The Influence of Music on Mental Effort and Driving Performance, dalam Accident Analysis \& Prevention. Volume 48, September 2012, 271-278. 